\title{
THE BUSINESS ENVIRONMENT OF SMALL AND MEDIUM-SIZED ENTERPRISES IN SELECTED REGIONS OF THE CZECH REPUBLIC AND SLOVAKIA
}

\section{Jaroslav Belás, Valér Demjan, Jozef Habánik, Mária Hudáková, Juraj Sipko}

\section{Introduction}

The business environment of small and mediumsized enterprises (SMEs) is a current area of theoretical research and practical applications in the European Union. The financial crisis and the gradual recovery of the economies in the European Economic Area brought about a deterioration of the business environment. It can be assumed that business risks have increased due to turbulence in the economic system. SMEs are currently operating in a more demanding economic environment, and many of them are struggling to survive.

The fundamental prerequisite for successful management and the development of all businesses is a favourable business environment in which the state supports and protects economic competition, creates clear and stable rules, and effectively ensures compliance by all market participants while minimizing administrative barriers towards entrepreneurs. A positive perception of the business situation by society might mean a greater interest in starting a business, which can further lead to a higher rate of GDP and higher employment rates. Generally, it is the prevailing opinion that countries with better conditions for doing business achieve also a higher standard of living.

In this article, the current situation of the business environment of SMEs in selected regions of the Czech Republic and Slovakia has been examined. Our research was dealing with socio-economic parameters of the business environment such as motivational factors, status in society, level of corruption, business risks, approach to debt finance, ability to manage financial risks and business optimism.

\section{Theoretical Aspects of SMEs Business, the Business Environment, Risks, Debt Financing of SMEs}

SMEs have become an increasingly important component of economic development, representing a substantial proportion of national economies worldwide [21]. In this context, Henderson and Weiler indicate that SMEs can be characterized as a major engine of economic growth. [20]

The European Commission [11, p. 4] states that "the source of lifeblood" of the European economy lies in 23 million small and mediumsized companies which represent more than $98 \%$ of the business community. They provide two-thirds of the total employment in the private sphere, and over the last five years, they have created approximately $80 \%$ of new jobs.

SMEs play an important role in the economic systems of the Czech Republic and Slovakia. In 2012, the share of SMEs in the total number of active enterprises in the Czech Republic was $99.86 \%$ while the share of added value was $53.81 \%$. The share of SME employees in the total employment in the business sector in the Czech Republic was $59.43 \%$ in 2012. [31] In Slovakia, the share of SMEs in the total number of active enterprises was $99.2 \%$; in the total employment it was $59.5 \%$. The share of added value was $55.6 \%$ and the share of SMEs in the profit before taxes was $51.6 \%$. [35]

Entrepreneurial orientation is important for SMEs. Soininen et al. [41] consider innovativeness, risk-taking and proactivity as the basic characteristics of entrepreneurial orientation. Their results do not support the assumption that entrepreneurial orientation is positively related to the profitability of small 
firms. On the other hand, there is a positive relationship between the entrepreneurial orientation of a firm and a firm's rate of growth.

According to Eggers et al. [10], to drive growth, a firm will need to deploy a strategy centred on entrepreneurial orientation. Authors indicated that entrepreneurial orientation is positively related to SME growth, but customer orientation shows a negative association with the growth. Anderson and Eshima [2] examined the influence of the firm age and intangible resources on the relationship between the entrepreneurial orientation and the firm growth. [42]

Hamilton argues that initial employment size, rather than age, was found to have some bearing on the nature of the growth path. Smaller firms grew more often and with more continuity than larger firms. In larger firms, the growth occurred in relatively large isolated steps with little continuity. [18]

Avlonitis and Salavou note that active entrepreneurs do not like passive entrepreneurs and adopt a more aggressive orientation characterized by the willingness to undertake an action of high risk before their competition. Nonetheless, proactiveness contrary to risktaking is found to be an important contributor to the performance of new products introduced by both groups. [4]

Lasagni investigated the role of external relationships as key drivers of small business innovation. Her results indicate that innovation performance is higher in SMEs that are proactive in strengthening their relationships with innovative suppliers, users, and customers. [27] In this context, Kraus et al. state that innovative SMEs do perform better in a turbulent environment. [25]

Keh, Nguyen and $\mathrm{Ng}$ examined the influence of entrepreneurial orientation and marketing information on the performance of SMEs and indicated that entrepreneurial orientation plays an important role in enhancing firm performance. Information utilization has a positive impact on firm performance, and there is a positive relationship between information utilization and making marketing decisions and the subsequent firm performance. [22]

A wide range of authors deal with SME management, e.g. [30], [33] According to Fetisovová, Vlachynský and Sirotka, basic business risks of SMEs include, e.g., limited access to loans, small capital strength, increased competition, high tax and levy burden, low level of management skills, low level of diversification, administrative complexity, risk of failure, and connection between work and private life. [13] In this context, Hasle et al. state that most owner-managers take a positive approach to the working environment, but also try to "talk risk down," criticize regulation as bureaucracy and place part of the employer responsibility onto the employees. [19]

The Association for Financial Professionals in collaboration with Zanders Treasury and Finance Solutions conducted in 2013 an international survey called the Treasury Risk Survey, which was focused on global trends in corporate risk management. According to this survey, among the most serious threats to European companies are liquidity risk, foreign currency risk and reputation risk. Great attention is paid to business and counterparty risk - whether it is represented by credit risk related to customers or by the financial stability of suppliers, banks and other providers of funding. [6]

A particularly important issue to SMEs is the financial gap produced by their limited access to external financing. Even before the economic downturn, some of the small businesses had troubles obtaining the funds necessary for growth and innovation. Due to the financial crisis, banks are even less willing to lend to companies in many countries, which further exacerbated the problems SMEs were already facing. [11]

In this context, Dierkes et al. argue that SMEs are smaller, more informationally opaque, riskier, and more dependent on trade credit and bank loans. [8] According to Canales and Nanda, small businesses, and particularly young small businesses, have little internal cash flow to finance their operations and are also associated with significant asymmetric information. [5]

According to Majková-Sobeková, the high risk of SMEs is characterized by a high level of debt and a limited capacity to guarantee. As such, the acquisition of commercial loans for such companies is highly problematic. [29] In this context, Di Giuli, Caselli and Gatti report that for SMEs, credit availability is a vital developmental element. [9]

According to Neuberger and Räthke, micro-enterprises are especially predisposed to incorrect selection and moral hazard, and therefore their access to debt financing is limited. Small firms are characterized by higher 
information asymmetry and credit risk. [37] This opinion is confirmed by Kirschenmann and Norden, who argue that information asymmetry and bargaining power are especially important in small business lending because small firms are informationally opaque and bankdependent. [23]

Moro and Fink reported that banks play an essential role in financing firms, especially SMEs, since they have more difficulty accessing equity capital markets. The process used by banks to decide whether and how much to lend relies on different lending technologies, and banks usually tend to use more than one technology at once. [34]

Business activities are significantly determined by the environment of the company, which forces it to use a particular method of behaviour and to choose particular business goals and ways of achieving them. In this context, important roles are played by the social environment and the political and legal environments that are created by the state authorities. Presumably, a positive perception of these companies by their environment could stimulate their financial performance and accelerate the positive influences of these companies on society.

\section{The Study's Aim, Methodology and Results}

The aim of this article was to define and compare current trends in the business environment of small and medium-sized enterprises in selected regions of the Czech Republic and Slovakia. In accordance with the objective, motivational factors, status in the society, level of corruption, current business risks, the approach to loan financing, the ability to manage financial risks and business optimism in the business environment have been examined.

The research of the business environment was conducted in 2013 in the select regions of the Czech Republic and Slovakia through a questionnaire. In the Zlin Region (ZL) of the Czech Republic, 180 SMEs were contacted; in the Zilina Region (ZA) of Slovakia, 164 SMEs were contacted; and in the Trencin Region (TN) of Slovakia, 105 SMEs were contacted. Each company's data was provided by their owners. In the Zlin Region, there were 107,000 SMEs in 2012. In the Zilina Region, there were 72,512 SMEs in 2012. In the Trenčín Region were 55,722 (including self-employed). [31], [32]
These regions have been chosen because of their common national border, long-term intensive economic cooperation and similar economic parameters. But at the same time, these regions are parts of different countries, allowing us to compare the effectiveness of economic policy towards SMEs in these regions.

The Zlin Region has an area of $3,964 \mathrm{~km}^{2}$ and about 600,000 inhabitants. In 2012, the GDP per capita was about 11,720 EUR, and the unemployment rate was about $8 \%$.

The Zilina Region has an area of $6,800 \mathrm{~km}^{2}$. The total population is approximately 700,000 and the population density is 102 inhabitants per $\mathrm{km}^{2}$. The unemployment rate increased to $11.91 \%$ in 2011 . The GDP per capita that year was 10,794 EUR.

The Trencin Region has an area of 4,502 $\mathrm{km}^{2}$ and has about 600,000 inhabitants. The GDP per capita reached 10,744 EUR in 2010 $(88.57 \%$ of the average GDP per capita in Slovakia), and the registered unemployment rate was at $10.89 \%$ in 2012 (significantly below the national average of $14.44 \%$ ). This region has a strong industrial tradition, reflected in the fact that the share of the industry on GDP reached the level of $33.96 \%$ in 2010 which significantly exceeded the national average of $26.46 \%$. However, this region is struggling with transformation problems and needs to increase dynamic adaptation to the knowledge economy conditions particularly in the sectors of information, communication, technical, scientific and administrative services. The share of these sectors in the GDP formation reaches only $7.85 \%$, which is substantially lower than the share of these sectors which contributes to the GDP formation of Slovakia (12.26\%).

In our research on the Zlin Region, the largest share of SMEs was operating in trade activities $(35 \%)$, followed by manufacturing companies $(29 \%)$, construction firms (12\%), transport companies (4\%), and agricultural enterprises $(3 \%)$. The remaining share was formed of companies operating in other sectors.

In the Zilina Region, the structure of companies was as follows: $17 \%$ of companies operated in the manufacturing sector, $21 \%$ in the trade sector, $17 \%$ in the construction sector, $6 \%$ in the transport sector, $1 \%$ in the agricultural sector. The largest portion of companies operated in other sectors (38\%).

In the Trencin Region, the structure of companies was as follows: manufacturing 
companies $(21 \%)$, trade companies $(21 \%)$, construction companies (18\%), transport companies (4\%) and agricultural firms (5\%). The largest portion of companies operated in other sectors (31\%).

From the total number of 180 surveyed firms in the Zlin Region, $70 \%$ of them were doing business more than 10 years, $21 \%$ of them between 5 and 10 years, and $9 \%$ of them between 1 and 5 years. Therefore, the study was examining quite experienced entrepreneurs. The age structure of companies was as follow: $58 \%$ were micro-enterprises, $31 \%$ were small enterprises and $11 \%$ were medium-sized companies.

From the total number of 164 surveyed firms in the Zilina Region, $38 \%$ were doing business more than 10 years, $32 \%$ of them between 5 and 10 years, 30\% of them between 1 and 5 years. Therefore it can be stated that companies were equally distributed regarding the length of doing business. The age structure of companies was as follows: $66 \%$ were microenterprises, $20 \%$ were small enterprises and $14 \%$ were medium-sized companies.

From the total number of 105 surveyed companies in the Trencin Region, 54\% of the companies had been in business more than 10 years, $25 \%$ from 5 to 10 years, and $21 \%$ from 1 to 5 years. The size structure of the companies was as follows: $62 \%$ were micro-enterprises, $31 \%$ were small enterprises and $7 \%$ were medium-sized enterprises.

In our research, we examined if there were statistically solid differences in several attributes among SMEs in the selected regions of Slovakia and the Czech Republic according to their field, age and size. In detail, we quantified the differences between the trading companies and the others, between the companies over 10 years old and the others and between the micro-enterprises and the others.

The business environment is determined by personal characteristics and motives of individual entrepreneurs. Creativity, risk taking and independence increase the probability of becoming an entrepreneur and decrease the probability of becoming an employee. [24]

Almeida, Ahmetoglu, and ChamorroPremuzicshow thattheMETAmodel(Awareness, Vision, Creativity, and Opportunism) is the strongest and the most consistent predictor of an entrepreneurial activity. Entrepreneurial individuals are characterized primarily as enterprising and creative, and to some degree as social and investigative. [1]

According to the survey of PwC, the major motivations among Czech entrepreneurs to run one's own business are the wish to be free in decisions and a passion for the field of business. Only after these attributes were financial motivation, success and prestige mentioned. [39] A survey by GE Money Bank listed these as the most important motivations: desire for money, flexible working hours, a certain lifestyle and the necessity of independence. [14]

In line with previous findings, we hypothesize the following:

$\mathrm{H} 1$ : The major motivation to run one's own company in the region of Zlin is money.

H1a: There exist no significant differences in the motivation to run one's own business between the regions of Zlin and Zilina and between the regions of Zlin and Trencin.

$\mathrm{H} 1 \mathrm{~b}$ : Less than $20 \%$ of entrepreneurs in the region of Zlin started their own business because they perceive it as their mission.

H1c: Less than $20 \%$ of entrepreneurs in the regions of Zilina and Trencin started their own business because they perceive it as their mission.

$\mathrm{H} 1 \mathrm{~d}$ : Money as the motivation to run one's own business is assessed the same, irrespective of the field, the age and the size of a company.

Various surveys show the perception of entrepreneurship by society is still relatively negative in Slovakia and the Czech Republic. For instance, according to the survey of the National Agency for Development of Small and Medium Enterprises, $69.9 \%$ of respondents think entrepreneurs in Slovakia just try to quickly achieve as high profits as possible, $78.2 \%$ believe entrepreneurs are getting rich by taking advantage of ordinary people and are abusing their employees. [36] GfK Czech (2013) argues that $45 \%$ of the Czech inhabitants perceive entrepreneurs in a negative way. [16]

Therefore, we hypothesize the following:

$\mathrm{H} 2$ : There are no statistically significant differences in the perception of entrepreneurs by society between the regions of Zlin and Zilina and between the regions of Zlin and Trencin.

$\mathrm{H} 2 \mathrm{a}$ : Less than $10 \%$ of entrepreneurs in the region of Zlin think that society perceives them positively.

$\mathrm{H} 2 \mathrm{~b}$ : The assessment of positive perception of entrepreneurship by society is the same, 
irrespective of the field, the age and the size of a company.

The relationship between the state and entrepreneurs is complicated in the long run, as these entities have opposite ideas about how to manage the economy.

Entrepreneurs generally evaluate the approach of the state to their needs and interests negatively. As it was revealed in a survey by the web server Podnikatel.cz (2013), most business owners spend even entire days filling out forms. The vast majority of entrepreneurs believe that the talk of reducing administrative burdens in the Czech Republic is meaningless. According to $59 \%$ of Czech businessmen, the bureaucratic burden has been increasing in recent years. [38]

The study of the World Bank called Doing Business 2014 presents the current situation of the business environment in the Czech Republic, and also the development of this situation. In the overall ranking, the Czech Republic has fallen 7 points in the last year to $75^{\text {th }}$ place, ending up just behind Romania and the Republic of Vanuatu. All of the Czech Republic's neighbours were ranked higher: Slovakia was ranked $49^{\text {th }}$, Poland $45^{\text {th }}$, Austria $30^{\text {th }}$ and Germany $21^{\text {st }}$. Furthermore, the Czech Republic also has a disastrous outcome in assessing the ease and cost of starting a business. Out of 189 countries, the Czech Republic was ranked in $146^{\text {th }}$ position, a drop of 6 points in comparison to the previous year. To start a business in the Czech Republic, you must undertake an average of 9 procedures. The average value for OECD at the same time is 5 procedures. In the Czech Republic, you can create a company in 19.5 days, whereas the OECD average value is 11 days. [38]

The business environment in Slovakia was negatively perceived by $56 \%$ of companies in 2013. This was determined by an economic survey conducted by the Slovak Chamber of Commerce among its members. [40]

Based on this, we hypothesize the following:

H3: There exist no significant differences in the opinions of entrepreneurs about the state attitude to their needs between the regions of Zlin and Zilina and between the regions of Zlin and Trencin.

$\mathrm{H} 3 \mathrm{a}$ : Less than $10 \%$ of entrepreneurs in the region of Zlin uphold that the state fulfils its duties and helps them in their activities.
$\mathrm{H} 3 \mathrm{~b}$ : The intensity of positive assessment of the state activities by entrepreneurs is the same, irrespective of the field, the age and the size of a company.

Corruption represents a serious problem in both countries. According to the reports of the Security and Intelligence Service of the Czech Republic (BIS), there exist widespread corruption activities and the ciphering off of public funds by private parties through outsourcing, projects of public and private sector partnerships, the manipulation of public contracts and the misuse of European subsidies in the country. These activities, however, could not exist without considerable help from politicians in both countries. [17] According to a survey by the Association of Small and Medium Entrepreneurs and the Self-Employed of the Czech Republic, $59.3 \%$ of entrepreneurs think it is not possible to obtain a public contract in the Czech Republic without giving special provisions or bribes. The average provision was $15.7 \%$ of the amount of the contract. [3] Moreover, a survey by Ernst \& Young indicated that $69 \%$ of Czechs consider corruption in running one's business to be a widespread phenomenon. [28]

According to Transparency International, the Czech Republic in perception of corruption occupied $54^{\text {th }}$ place in 2012 (Slovakia was in the $62^{\text {nd }}$ position). These results point out that corruption both in perception and practice is strong in both countries. [17]

Based on these findings, we hypothesize the following:

H4: The perceived degree of corruption in the region of Zlin is lower than in the regions of Zilina and Trencin.

$\mathrm{H} 4 \mathrm{a}$ : At least $50 \%$ of entrepreneurs in the region of Zlin have experienced corruption and cronyism in their business activities.

$\mathrm{H} 4 \mathrm{~b}$ : The perception of corruption by entrepreneurs in the selected regions is the same regardless the field, the age and the size of a company.

According to Fetisovová et al., the financial and economic crisis has had serious implications on the performance of small and medium-sized companies in the European Union. In 2009, the gross production of SMEs within the EU27 decreased by $5.5 \%$. Insufficient effective demand was the most urgent issue for 
$29 \%$ of these SMEs. The authors report that the demand in the domestic markets of the EU27 will remain weak. [12]

A particularly important problem of SMEs is a financial gap since many of these companies have limited access to external financial sources. Even before the economic downturn, some small businesses were having trouble accessing the funds necessary for growth and innovation. As a consequence of the financial crisis, banks in many countries are even less willing to lend to businesses, which further escalates the problems faced by companies. [11] According to Fetisovová et al., the approach to financial resources for SMEs represents a serious problem for SMEs. However, in the short term, it is less urgent than the lack of demand on domestic markets. [12]

The global financial crisis has caused considerable concerns about what the banks' practices will be in relation to the loan financing of the corporate sector. The current signals confirm that banks in the Czech Republic and Slovakia have tightened the conditions for their clients. A highly unfavourable situation can be observed from the perspective of companies because of restrictions on the business community in relation to financing by bank instruments. [15] In this context, Cowling, Liu, and Ledger state that generally, loans were more readily available to larger and older firms throughout the recession. At its peak, 119,000 ( $10 \%$ of the total stock) smaller firms in the UK were denied credit in a three-month period. [7]

As a consequence of such findings, we hypothesize the following:

H5: The most important business risk in all regions is, according to entrepreneurs, the market risk.

$\mathrm{H} 5 \mathrm{a}$ : The average value of the market risk in the region of Zlin is higher than $40 \%$.

$\mathrm{H} 5 \mathrm{~b}$ : Entrepreneurs in the region of Zlin are facing a market risk less intensive than entrepreneurs in the regions of Zilina and Trencin.

$\mathrm{H} 5 \mathrm{c}$ : The evaluation of the market risk by entrepreneurs is the same irrespective of the field, the age and the size of a company.

H6: In the region of Zlin, the average decrease in the performance of SMEs is at least $15 \%$ in comparison to the period before the crisis.

H6a: There exist no significant differences in the structure of performance decrease of
SMEs between the regions of Zlin and Zilina and between the regions of Zlin and Trencin.

$\mathrm{H} 6 \mathrm{~b}$ : The structure of performance decrease of SMEs is not correlated with the field, the age and the size of a company.

$\mathrm{H7}$ : The entrepreneurs in the selected regions assess the approach of banks to their financial needs at the same level.

$\mathrm{H} 7 \mathrm{a}$ : Less than $50 \%$ of entrepreneurs in the region of Zlin think that banks accept their needs and behave in an appropriate way.

H7b: The positive assessment of the banks' behaviour by entrepreneurs does not depend on the field, the age and the size of a company.

The financial crisis has significantly changed the view on risk management in the SME segment in European countries, including Slovakia. Based on many studies dealing with corporate management in Slovakia and published during the crisis, the most common failures, which can substantially affect the potential ability of a company to survive during the crisis, were for example mismanagement of cash flows or insufficient management of financial risks, i.e., the lack of an early warning from the financial manager. [26]

Based on this, the following hypotheses were formulated:

H8: The evaluation of the entrepreneurs' abilities to manage risks is the same in all the selected regions.

H8a: At least $90 \%$ of entrepreneurs in the region of Zlin think they can manage financial risks in their companies properly.

$\mathrm{H} 8 \mathrm{~b}$ : Entrepreneurs in the region of Zlin are more self-assured they can manage financial risks compared to entrepreneurs in the regions of Zilina and Trencin.

H8c: The perceived ability to manage financial risks in a company does not depend on the field, the age and the size of a company.

According to PwC, nearly $70 \%$ of the owners of Czech companies expected growth of their businesses in the short term. This growth should have been achieved through the acquisition of new customers and the further penetration of existing clients. Entrepreneurs explained that the biggest threat to their growth is the existence of intense low-cost competition, which they will compete with by producing higher quality products and taking better care of their customers. [39] 
Therefore, we hypothesize the following:

H9: The optimism among entrepreneurs is the same in all the selected regions.

H8a: At least $90 \%$ of entrepreneurs in the region of Zlin believe their company will survive the next five years.

$\mathrm{H} 9 \mathrm{~b}$ : The optimism among entrepreneurs is at higher levels in the region of Zlin than it is in both selected Slovak regions.

H9c: The level of optimism among entrepreneurs does not depend on the field, the age and the size of a company.

The associations in contingency tables were analysed by Pearson statistics for count data.
The $\mathrm{P}$-value is being compared with the standard $5 \%$ confidence level. A P-value lower than the confidence level leads to the rejection of the null hypothesis. The null claims there is no association between variables. Calculations have been performed using statistical packages $\mathrm{XL}$ Statistics and R. Finally, instruments of descriptive statistics, such as percentages and averages have been used.

\section{Results}

Firstly, the motivation to start one' s own business has been investigated. The obtained results and their comparison are shown in the Table 1.

Tab. 1: Motivation to start a business in the Czech Republic (CR) and Slovakia (SR

\begin{tabular}{l|c|c|c|c}
$\begin{array}{l}\text { What was your motive for starting } \\
\text { a business? }\end{array}$ & $\begin{array}{c}\text { CR (ZL) } \\
\text { in \% }\end{array}$ & $\begin{array}{c}\text { SR (ZA) } \\
\text { in \% }\end{array}$ & $\begin{array}{c}\text { SR (TN) } \\
\text { in \% }\end{array}$ & $\begin{array}{c}\text { p-value } \\
\text { ZL:ZA/ } \\
\text { ZL:TN }\end{array}$ \\
\hline 1. Money & 21.11 & 48.78 & 38.10 & $<0.01 /<0.01$ \\
\hline 2. I perceive it as a mission & 20.56 & 10.98 & 12.38 & $0.0230 / 0.1121$ \\
\hline 3. I wanted to have a job & 29.44 & 21.95 & 26.66 & $0.1438 / 0.7148$ \\
\hline 4. I had no choice & 10.00 & 7.92 & 11.43 & $0.6297 / 0.8579$ \\
\hline $\begin{array}{l}\text { 5. Other reasons (independence, } \\
\text { flexibility, etc.). }\end{array}$ & 18.89 & 10.37 & 11.43 & $0.0385 / 0.1377$ \\
\hline \multicolumn{2}{c|}{ p-value<0.01/0.0165 } & & &
\end{tabular}

The results of our research show that the major motive for starting one's own business in the region of Zlin is the wish to have a job. Thus $\mathrm{H} 1$ was not confirmed. Moreover, our research demonstrated statistically significant differences in the motives to start a business between the regions of Zlin and Zilina ( $p$-value $<0.01$ ) and between the regions of Zlin and Trencin ( $p$-value $=0.0165)$. The most important driver to start one's own business is money in both selected Slovak regions ( $p$-value in both cases $<0.01$ ). Entrepreneurs of the Zlin Region stated more often than entrepreneurs of the Trencin Region that they perceive their business as their mission ( $p$-value $=0.0230$ ). $\mathrm{H} 1 \mathrm{a}$ was not confirmed. $\mathrm{H} 1 \mathrm{~b}$ was not confirmed either, as the $p$-value was calculated at 0.5371 . On the contrary, p-values for the Zlin Region (0.0110) and the Trencin Region (0.0336) confirmed the validity of $\mathrm{H} 1 \mathrm{c}$, which means that less than $20 \%$ of entrepreneurs in both regions started their business because they perceive it as their mission.

H1d was partially confirmed. We found no statistically significant differences in the assessment of money as the major driver of running one's own business between the trading companies and the others, between the companies over 10 years old and the others and between the micro-enterprises and the others. The only exception was found among younger companies in the Zlin Region. The companies under 10 years old stated money as the major motive for starting their business more often than the other companies ( $p$-value $=0.0063$ ).

The status of an entrepreneur was examined in the following questions. The results are shown in Tables 2 and 3. 
Tab. 2: How entrepreneurs are perceived by society in the Czech Republic and Slovakia

\begin{tabular}{l|c|c|c|c}
$\begin{array}{l}\text { Do you think that our society } \\
\text { (politicians, public opinion, media) } \\
\text { perceive the position and activities } \\
\text { of entrepreneurs correctly? }\end{array}$ & $\begin{array}{c}\text { CR(ZL) } \\
\text { in \% }\end{array}$ & $\begin{array}{c}\text { SR(ZA) } \\
\text { in \% }\end{array}$ & $\begin{array}{c}\text { SR(TN) } \\
\text { in \% }\end{array}$ & $\begin{array}{c}\text { p-value } \\
\text { ZL:ZA } \\
\text { ZL:TN }\end{array}$ \\
\hline $\begin{array}{l}\text { 1. No, our society perceives us } \\
\text { negatively }\end{array}$ & 20.56 & 15.85 & 20.95 & $0.3238 / 1.0000$ \\
\hline 2. Society perceives us incorrectly & 42.22 & 43.30 & 55.24 & $0.9272 / 0.0454$ \\
\hline 3. Society perceives us positively & 7.78 & 6.70 & 1.90 & $0.8618 / 0.0701$ \\
\hline 4. I am not thinking about it & 29.44 & 34.15 & 21.91 & $0.4121 / 0.2114$ \\
\hline \multicolumn{2}{r|}{$p$-value=0.6165/0.0485 } & & &
\end{tabular}

Source: own

The results shown in Table 2 confirmed there are significant differences in the perception of entrepreneurs by society between the Zlin and Trencin Regions ( $p$-value $=0.0485$ ). Differences between the Zlin and Zilina region were not found $(p$-value $=0.6165)$ in this issue. $\mathrm{H} 2$ was partially confirmed.

On the basis of the calculated test criteria ( $p$-value=0.1923), we argue that the rate of entrepreneurs thinking society perceives them positively in the Zlin Region is higher than $10 \%$. $\mathrm{H} 2 \mathrm{a}$ was not confirmed. To compare, the rate of entrepreneurs that think society perceives them positively is more than $10 \%(p$-value $=0.1011)$ in the region of Zilina and is lower than $10 \%$ in the region of Trencin ( $p$-value $<0.05$ ).

$\mathrm{H} 2 \mathrm{~b}$ was confirmed. The companies think society perceives them positively regardless of the field, the age and the size of a company.

Tab. 3:

The state approach towards entrepreneurs' needs in the Czech Republic and Slovakia

\begin{tabular}{l|c|c|c|c}
$\begin{array}{l}\text { How do you assess the state } \\
\text { attitude to entrepreneurs' needs? }\end{array}$ & $\begin{array}{c}\text { CR(ZL) } \\
\text { in \% }\end{array}$ & $\begin{array}{c}\text { SR(ZA) } \\
\text { in \% }\end{array}$ & $\begin{array}{c}\text { SR(TN) } \\
\text { in \% }\end{array}$ & $\begin{array}{c}\text { p-value } \\
\text { ZL:ZA } \\
\text { ZL:TN }\end{array}$ \\
\hline 1. I feel the state is just bullying us & 42.22 & 53.05 & 54.29 & $0.0574 / 0.0649$ \\
\hline 2. The state is not fulfilling its duties & 42.22 & 38.41 & 40.95 & $0.5427 / 0.9321$ \\
\hline 3. The state is fulfilling its duties & 12.78 & 5.49 & 4.76 & $0.0324 / 0.0469$ \\
\hline $\begin{array}{l}\text { 4. The state helps us in our business } \\
\text { activities }\end{array}$ & 2.78 & 3.05 & 0 & $1.0000 /-$ \\
\hline \multicolumn{2}{c|}{$p$-value=0.0605 /0.0170 } & & &
\end{tabular}

Source: own

The results of the research stated in Table 3 point out significant variations in the opinions of entrepreneurs of the Zlin Region and the Trencin Region ( $p$-value $=0.0170$ ). Although there were solid differences between entrepreneurs of the Zlin Region and the Zilina Region, these were not statistically significant ( $p$-value $=0.0605$ ). As a result, $\mathrm{H} 3$ was not confirmed.

Judging from the calculated $\mathrm{p}$-value at 0.9900 , we cannot argue that less than $10 \%$ of entrepreneurs in the Zlin Region think the state fulfils its duties and helps the business sector. H3a was not confirmed.

On the other side, $\mathrm{H} 3 \mathrm{~b}$ was confirmed. The intensity of the positive assessment of the state activities by entrepreneurs (line 3 and line 4 in the Table 3 ) is the same in the selected regions regardless of the field, the age and the size of a company.

The level of corruption was examined through one question, answers to which are presented in Table 4. 


\begin{tabular}{|c|c|c|c|c|}
\hline $\begin{array}{l}\text { Have you ever experienced the } \\
\text { corruption and cronyism in your } \\
\text { business activities? }\end{array}$ & $\begin{array}{c}\text { CR(ZL) } \\
\text { in \% }\end{array}$ & $\begin{array}{c}\text { SR(ZA) } \\
\text { in \% }\end{array}$ & $\begin{array}{c}\text { SR(TN) } \\
\text { in \% }\end{array}$ & $\begin{array}{l}\text { p-value } \\
\text { ZL:ZA/ } \\
\text { ZL:TN }\end{array}$ \\
\hline 1. yes & 53.33 & 71.95 & 75.96 & $<0.01 /<0.01$ \\
\hline 2. no & 46.67 & 28.05 & 24.04 & $<0.01 /<0.01$ \\
\hline$p$-value $<0.01 /<0.01$ & & & & \\
\hline
\end{tabular}

Source: own

According to our research, the perception of corruption was different in the Czech Republic and Slovakia. The perceived corruption is at a statistically significant lower level in the region of Zlin than in the regions of Zilina or Trencin. In both cases the p-value was lower than 0.01 , thus $\mathrm{H} 4$ was not confirmed.

Judging from the calculated $p$-value (0.2060), it cannot be argued that at least $50 \%$ of entrepreneurs from the Zlin Region have experienced corruption and cronyism in their business activities. Consequently, $\mathrm{H} 4 \mathrm{a}$ was not confirmed.

However, H4b could be accepted. Our research confirmed the perception of corruption is the same, irrespective of the field, the age and the size of a company.

Table 5 shows the results of the survey concerning business risks of SMEs in the selected regions of the Czech Republic and Slovakia.

\section{Tab. 5: The identification of business risks in the Czech Republic and Slovakia}

\begin{tabular}{|c|c|c|c|c|}
\hline $\begin{array}{l}\text { Doing your business, you face } \\
\text { many risks. Which risks do you } \\
\text { consider as currently crucial? } \\
\text { (Please provide a maximum of } \\
\text { three answers) }\end{array}$ & $\begin{array}{l}\text { CR(ZL) } \\
\text { in \%* }\end{array}$ & $\begin{array}{l}\text { SR(ZA) } \\
\text { in \%** }\end{array}$ & $\begin{array}{l}\text { SR(TN) } \\
\text { in \%* }\end{array}$ & $\begin{array}{c}\text { p-value } \\
\text { ZL:ZA/ZL:TN }\end{array}$ \\
\hline $\begin{array}{l}\text { 1. market risk (lack of contracts) } \\
\text { Average value } \\
\text { Adjusted average value }\end{array}$ & $\begin{array}{l}79.44 \\
56.00 \\
44.49 \\
\end{array}$ & $\begin{array}{l}80.49 \\
51.30 \\
41.29\end{array}$ & $\begin{array}{l}82.86 \\
53.27 \\
44.14\end{array}$ & $0.9150 / 0.5833$ \\
\hline $\begin{array}{l}\text { 2. financial risk (poor approach to } \\
\text { company's financing) }\end{array}$ & 57.22 & 58.54 & 50.48 & $0.8910 / 0.3269$ \\
\hline $\begin{array}{l}\text { 3. operational risk (mishandling of } \\
\text { processes) }\end{array}$ & 20.56 & 22.56 & 14.29 & $0.7480 / 0.2448$ \\
\hline 4. personnel risk (poor quality staff) & 43.33 & 38.41 & 47.62 & $0.4140 / 0.5631$ \\
\hline 5. legal risk & 30.56 & 37.20 & 32.38 & $0.2350 / 0.8507$ \\
\hline $\begin{array}{l}\text { 6. safety risk (accidents, incidents, } \\
\text { etc.) }\end{array}$ & 21.67 & 32.93 & 27.62 & $0.0260 / 0.3206$ \\
\hline
\end{tabular}

Note: * data are calculated as the ratio of respondents which stated given answer to the total number of companies; ** average of values reported by entrepreneurs in individual regions; ${ }^{* \star *}$ means the average values from the total file

Source: own

The data in Table 5 show the major business risk in all the regions is market risk. The validity of $\mathrm{H} 5$ was confirmed. Since the average value of the market risk in the region of Zlin was more than $40 \%$, $\mathrm{H} 5 \mathrm{a}$ was confirmed as well. However, H5b was not confirmed, because the entrepreneurs in all the regions perceive the intensity of market risk at the same level. $\mathrm{H} 5 \mathrm{c}$ was confirmed: the perception of market risk in the selected regions is the same regardless the field, the age or the size of a company. 
Tab. 6: The development of SME performances in the Czech Republic and Slovakia

\begin{tabular}{|c|c|c|c|c|}
\hline $\begin{array}{l}\text { By what percentage has your } \\
\text { current performance decreased } \\
\text { compared to the pre-crisis period? }\end{array}$ & $\begin{array}{c}\text { CR(ZL) } \\
\text { in \% }\end{array}$ & $\begin{array}{l}\text { SR(ZA) } \\
\text { in \% }\end{array}$ & $\begin{array}{l}\text { SR(TN) } \\
\text { in \% }\end{array}$ & $\begin{array}{l}\text { p-value } \\
\text { ZL:ZA/ } \\
\text { ZL:TN }\end{array}$ \\
\hline 1. up to $10 \%$ & 17.24 & 17.07 & 19.09 & $1.0000 / 0.7408$ \\
\hline 2. 11 to $20 \%$ & 13.79 & 20.12 & 11.43 & $0.1590 / 0.7658$ \\
\hline 3. 21 to $30 \%$ & 17.24 & 20.73 & 20.95 & $0.4970 / 0.4667$ \\
\hline 4. 31 to $40 \%$ & 10.92 & 5.49 & 13.33 & $0.1070 / 0.6161$ \\
\hline 5.41 to $50 \%$ & 5.75 & 6.71 & 2.86 & $0.8890 / 0.6518$ \\
\hline 6. above $50 \%$ & 3.45 & 6.10 & 3.81 & $0.3730 / 0.6518$ \\
\hline $\begin{array}{l}\text { 7. my company's performance has } \\
\text { increased }\end{array}$ & 31.61 & 23.78 & 25.71 & $0.1380 / 0.4441$ \\
\hline \multicolumn{3}{|c|}{$p$-value $=0.1855 / 0.7832$} & & \\
\hline
\end{tabular}

Source: own

Table 6 presents the decrease of the performance of SMEs (according to their owners) in 2013 compared to the pre-crisis period.

The average decrease in the performance amounted to $15.80 \%$ in the Zlin Region (weighted average of upper values of individual intervals). $\mathrm{H} 6$ was confirmed. For a better overview, the average decrease in performance was $18.78 \%$ in the Zilina Region and $19.53 \%$ in the Trencin Region.

The values of test criteria stated in Table 6 ( $p$-value $=0.1855 / 0.7832)$ confirmed that there are no statistically significant differences between both countries in relation to the decrease or increase in performances. $\mathrm{H} 6 \mathrm{a}$ was disproved.

H6b was confirmed as we found out the change of performances of SMEs was not dependent on the field, the age or the size of a company.

The existence of the most important business risks resulted in tighter credit conditions by commercial banks. This trend is also perceived by SMEs, which can be seen in Table 7.

\section{Tab. 7:}

Commercial banks' approach to SME financing in the Czech Republic and Slovakia

\begin{tabular}{|c|c|c|c|c|}
\hline $\begin{array}{l}\text { How do you assess banks' } \\
\text { approach to the financing of small } \\
\text { and medium-sized enterprises? }\end{array}$ & $\begin{array}{l}\mathrm{CR}(\mathrm{ZL}) \\
\text { in } \%\end{array}$ & $\begin{array}{l}\text { SR(ZA) } \\
\text { in \% }\end{array}$ & $\begin{array}{l}\text { SR(TN) } \\
\text { in \% }\end{array}$ & $\begin{array}{c}\text { p-value } \\
\text { ZL:ZA/ZL:TN }\end{array}$ \\
\hline $\begin{array}{l}\text { 1. Banks fully accept our needs and } \\
\text { have a good relationship with us }\end{array}$ & 4.44 & 3.05 & 0.95 & 0.6930/- \\
\hline 2. Banks behave appropriately & 38.89 & 20.12 & 34.29 & $<0.01 / 0.5160$ \\
\hline 3. Banks behave unhelpfully towards us & 8.89 & 14.02 & 9.52 & $0.1830 / 1.0000$ \\
\hline $\begin{array}{l}\text { 4. Banks use too hard criteria for } \\
\text { lending }\end{array}$ & 26.11 & 37.20 & 43.81 & $0.0360 / 0.0030$ \\
\hline 5. I cannot judge & 21.67 & 25.61 & 11.43 & $0.4630 / 0.0440$ \\
\hline \multicolumn{2}{|l|}{$p$-value $<0.01 / 0.0110$} & & & \\
\hline
\end{tabular}


The results of the research shown in Table 7 have not proved the validity of $\mathrm{H} 7$. Entrepreneurs in the region of Zlin assess the approach of commercial banks to their needs differently than the entrepreneurs of the regions of Zilina and Trencin. The values of the test criteria proved this statement ( $p$-value $<0.01 / 0.0110$ ). In more detail, entrepreneurs of the Zlin Region evaluate the approach of commercial banks more positively than entrepreneurs of the regions of Zilina and Trencin. Nonetheless, even entrepreneurs of the Zlin Region do not assess the banks too positively. The calculated p-value $(<0.05)$ pointed that less than $50 \%$ of entrepreneurs in the Zlin Region think the banks meet their needs and behave appropriately. As a result, $\mathrm{H} 7 \mathrm{a}$ was confirmed.

$\mathrm{H} 7 \mathrm{~b}$ was partially confirmed. Generally speaking, the positive assessment of the bank approach is not dependent on the field, the age or the size of a company. The only exception was found in the evaluation by the micro-enterprises in the Zlin Region. These enterprises assessed the attitudes of banks less positively than the other enterprises ( $p$-value $=0.002$ ).

The ability to manage financial risks has been verified through one question. The results are shown in Table 8.

\section{Tab. 8: The ability of entrepreneurs to manage financial risks in the company}

\begin{tabular}{l|c|c|c|c}
$\begin{array}{l}\text { Do you think that you are able } \\
\text { to manage financial risks in your } \\
\text { company? }\end{array}$ & $\begin{array}{c}\text { CR(ZL) } \\
\mathbf{2 0 1 3} \\
\text { in \%* }\end{array}$ & $\begin{array}{c}\text { SR(ZA) } \\
\mathbf{2 0 1 3} \\
\text { in \%* }\end{array}$ & $\begin{array}{c}\text { SR(TN) } \\
\mathbf{2 0 1 3} \\
\text { in \%* }\end{array}$ & $\begin{array}{c}\text { p-value } \\
\text { ZL:ZA/ZL:TN }\end{array}$ \\
\hline 1. Yes & 41.11 & 23.17 & 31.43 & $<0.01 / 0.1323$ \\
\hline 2. To a certain extent & 55.00 & 67.68 & 57.14 & $0.0210 / 0.8183$ \\
\hline 3. No & 0.56 & 1.83 & 0.00 & $-/-$ \\
\hline 4. I cannot judge & 3.33 & 7.32 & 11.43 & $-/-$ \\
\hline $\begin{array}{l}\text { p-value= due to the small numbers in line 3 and line 4, these values cannot be } \\
\text { reliably calculated }\end{array}$
\end{tabular}

Source: own

$\mathrm{H} 8$ was neither confirmed nor disproved as it was not possible to calculate the value of the test criteria.

The validity of $\mathrm{H} 8 \mathrm{a}$ was confirmed as the $p$-value was calculated at the level lower than 0.01 . This means that at least $90 \%$ of entrepreneurs of the Zlin Region opine they can manage financial risks in their company in an appropriate way.

The results stated in Table 8 enable us to conclude there are statistically significant differences in the opinions of entrepreneurs of the Zlin Region and entrepreneurs of the Zilina Region regarding this issue. Zlin entrepreneurs are more self-confident as to their ability to manage financial risks than Zilina entrepreneurs ( $p$-value<0.01). On the other hand, there were no significant differences in the confidence of Zlin entrepreneurs and Trencin entrepreneurs. Our research confirmed $\mathrm{H} 8 \mathrm{~b}$ only partially.

Finally, $\mathrm{H} 8 \mathrm{c}$ was confirmed. The confidence about the ability to manage financial risks in a company does not depend on the field, the age or the size of a company.

The level of business optimism has been examined through the following question. Results are shown in Table 9.

The validity of $\mathrm{H} 9$ was partially confirmed. We found that the structure of answers was similar in the regions of Zlin and Zilina. However, it was not possible to calculate reliably the value of the test criteria for comparing the regions of Zlin and Trencin.

The calculated value of the test criteria ( $p$-value $=0.0174$ ) proved that at least $90 \%$ of the entrepreneurs in the Zlin Region believe their company will survive the next five years. However, the rate of optimistic entrepreneurs in both selected Slovak regions was lower than $90 \%$. Accordingly, both $\mathrm{H} 9 \mathrm{a}$ and $\mathrm{H} 9 \mathrm{~b}$ were confirmed.

$\mathrm{H} 9 \mathrm{c}$ was confirmed as well. Our research proved the level of business optimism in the selected regions is not related to the field, the age or the size of a company. 
Tab. 9: The level of business optimism in the Czech Republic and Slovakia

\begin{tabular}{l|c|c|c|c}
$\begin{array}{l}\text { Do you believe that your company } \\
\text { will survive the next 5 years? }\end{array}$ & $\begin{array}{c}\text { CR(ZL) } \\
\mathbf{2 0 1 3} \\
\text { in \% }\end{array}$ & $\begin{array}{c}\text { SR(ZA) } \\
\mathbf{2 0 1 3} \\
\text { in \% }\end{array}$ & $\begin{array}{c}\text { SR(TN) } \\
\mathbf{2 0 1 3} \\
\text { in \% }\end{array}$ & $\begin{array}{c}\text { p-value } \\
\text { ZL:ZA/ZL:TN }\end{array}$ \\
\hline 1. Definitely & 49.44 & 40.85 & 35.24 & $0.1360 / 0.0270$ \\
\hline 2. No & 0.56 & 2.44 & 0.00 & $0.3140 /-$ \\
\hline 3. With some concerns & 45.56 & 49.39 & 56.19 & $0.5430 / 0.1075$ \\
\hline 4. With serious concerns & 4.44 & 7.32 & 8.57 & $-/ 0.2461$ \\
\hline \multicolumn{4}{l|}{ p-value=0.1784/cannot be calculated correctly } \\
\hline
\end{tabular}

Source: own

\section{Conclusion}

The correct perception of entrepreneurs by society is important for the economic growth of a country. Our research showed that entrepreneurs in the selected regions of the Czech Republic and Slovakia think that society perceives them rather negatively. These opinions in the end influence the motives to start one's own business and the whole attitude to entrepreneurship. The most important catalyst of starting a business in both selected Slovak regions (Zilina and Trencin) was the desire to make money. On the other hand, the situation was different for the Zlin Region, where a wish to have a job was the most important. Furthermore, our research showed low levels of positive motivation to start a business. The rate of entrepreneurs stating they perceive their entrepreneurship as a mission was only $20.56 \%$ in the region of $Z$ lin, $10.98 \%$ in the region of Zilina and $12.38 \%$ in the region of Trencin.

Entrepreneurs within the selected regions share more-less the same negative opinion about the attitude of the state towards their activities. A significant number of entrepreneurs think the state literally bullies them, i.e., instead of helping them in their activities it creates meaningless barriers and obstacles.

The perception of corruption in both countries is relatively intense. As much as $53.33 \%$ of Zlin entrepreneurs, $71.95 \%$ of Zilina entrepreneurs and $75.96 \%$ of Trencin entrepreneurs declared they had experienced corruption and cronyism in their business activities.

The discussion about the problems of SMEs in the Czech Republic and Slovakia has for a long time been aimed mostly at the issues of levies, the quality of the legal systems and the support of SMEs by the state. Nevertheless, our research showed there have been different priorities for SMEs in recent years. For example, entrepreneurs perceive market risk very intensively. Judging from these findings, it is necessary to create systematic prerequisites for widening the market of SMEs through improving consumer confidence. The decrease of the domestic demand has led to the decline of SME performance over the last few years.

Worsening market conditions for SMEs have also encouraged tighter lending policies by commercial banks. According to our findings, $26.11 \%$ of entrepreneurs in the region of Zlin, $37.20 \%$ of entrepreneurs in the region of Zilina and $43.81 \%$ of entrepreneurs in the region of Trencin think banks use overly strict criteria when giving out loans. Only $4.44 \%$ of entrepreneurs in the Zlin Region, $3.05 \%$ of entrepreneurs in the Zilina Region and 0.95\% of entrepreneurs in the Trencin Region stated banks fully accept their needs and are helpful.

The optimism of economic entities is essential for the proper functioning of the whole economic system. Therefore the results of our research are promising. The majority of Czech and Slovak entrepreneurs believe they can properly manage financial risks in their companies and that their companies will survive the next five years despite the dramatic changes in the business environment resulting in decreases in SME performances in recent years. In more detail, $96.11 \%$ of entrepreneurs of the Zlin Region, $90.85 \%$ of entrepreneurs of the Zilina Region and $88.57 \%$ of entrepreneurs of the Trencin Region declared they can properly manage financial risks in their companies. Moreover, 95\% of Zlin entrepreneurs, $90.24 \%$ 
of Zilina entrepreneurs and $91.43 \%$ of Trencin entrepreneurs believe their companies will survive the next five years.

The Czech economy is often compared to the Slovak economy. For instance, Hájek and Režný analysed the development of the Czech economy in comparison to the Slovak economy over the past two decades. The authors report that from the date of the proclamation of the independent Czech and Slovak Republics, the GDP of the Czech Republic has increased by $68 \%$, but the GDP of Slovakia has increased by $128 \%$ during the same period. The economy of Slovakia achieved an average annual growth rate of $3.86 \%$ in the period $1994-2012$. The faster growth in the GDP of Slovakia was based on a lower tax burden, as well as on lower levels of redistribution (the share of public expenditures in the GDP) and more favourable conditions for business. [17]

Our research has also shown that entrepreneurs of the Zlin Region assess the conditions of the business environment more positively than do Zilina and Trencin entrepreneurs. The business environments in these regions have been compared through nine different variables, namely the motives to start a business, the perception of entrepreneurship by society, the support of the state, the perception of the corruption in business activities, the intensity of market risk, the decrease in performances, the approaches of banks to financing SMEs, the ability to manage financial risks and business optimism. In all these areas, entrepreneurs in the Czech region of Zlin evaluate the attributes of running a business more positively than their counterparts from the selected Slovak regions.

Naturally, our research has several limitations. The first is the number of surveyed enterprises; the second is the regional selection of companies. In spite of these limitations we truly believe this research highlights interesting issues to discuss in the process of forming the business environment in the Czech Republic and Slovakia both at regional and national levels.

In the future, we would like to explore the connections among personal features of entrepreneurs, their risk aversion and their financial performance.

This paper was supported by Project No. FaME/2013/MSPRISK: Current trends in the area of business risks of small and medium- sized enterprises in selected regions of the Czech Republic and Slovakia.

This paper was created at Tomas Bata University in Zlin and was supported by Project No. IGA/FaME/2013/010: Satisfaction mirror effect and bank financial performance.

\section{References}

[1] ALMEIDA, P. I. L., AHMETOGLU, G., CHAMORRO PREMUZIC, T. Who Wants to Be an Entrepreneur? The Relationship Between Vocational Interests and Individual Differences in Entrepreneurship. Journal of Career Assesment. 2014, Vol. 22, Iss. 1, pp. 102-112. ISSN 13620436. doi:10.1177/1069072713492923.

[2] ANDERSON, B. S., ESHIMA, Y. The influence of firm age and intangible resources on the relationship between entrepreneurial orientation and firm growth among Japanese SMEs. Journal of Business Venturing. 2013, Vol. 28, Iss. 3, pp. 413-429. ISSN 0883-9026. doi:10.1016/j.jbusvent.2011.10.001.

[3] ASOCIACE MALÝCH A STŘEDNÍCH PODNIKŮ A ŽINOSTNÍKU゚. Názory podnikatelů na korupci [online]. Praha: AMSP ČR, 2010 [cit. 2014-07-07]. Available from: http://www.amsp. cz/uploads/soubory/pruzkum4_web_final.pdf.

[4] AVLONITIS, G. J., SALAVOU, H. E. Entrepreneurial orientation of SMEs, product innovativeness, and performance. Journal of Business Research. 2007, Vol. 60, Iss. 5, pp. 566-575. ISSN 0148-2963. doi:10.1016/j. jbusres.2007.01.001.

[5] CANALES, R., NANDA, R. A darker side to decentralized banks: Market power and credit rationing in SME lending. Journal of Financial Economics. 2012, Vol. 105, Iss. 2, pp. 353-366. ISSN 0304-405X. doi:10.1016/ j.jfineco.2012.03.006.

[6] CFO. Risk manažment: The most important risks for the European Companies [online]. CFO, 2014 [cit. 2013-07-11]. Available from: http://www.cfo.sk/articles/risk-manazmentnajvacsie-rizika-ktorym-celia-europske-firmy\#. UqA1QcTuLy.

[7] COWLING, M., LIU, W., LEDGER, A. Small business financing in the UK before and during the current financial crisis. International Small Business Journal. 2012, Vol. 30, No. 7, pp. 778-800. ISSN 0266-2426. doi:10.1177/0266242611435516.

[8] DIERKES, M., ERNER, C., LANGER, T., NORDEN, L. Business credit information 
sharing and default risk of private firms. Journal of Banking \& Finance. 2013, Vol. 37, Iss. 8, pp. 2867-2878. ISSN 0378-4266. doi:10.1016/ j.jbankfin.2013.03.018.

[9] DI GIULI, A., CASELLI, S., GATTI, S. Are small family firms financially sophisticated? Journal of Banking \& Finance. 2011, Vol. 35, Iss. 11, pp. 2931-2944. ISSN 0378-4266. doi:10.1016/j.jbankfin.2011.03.021.

[10] EGGERS, F., KRAUS, S., HUGHES, M., LARAWAY, E., SNYCERSKI, S. Implications of customer and entrepreneurial orientations for SME growth. Management Decision. 2013, Vol. 51, Iss. 3, pp. 524-546. ISSN 0025-1747. doi:10.1108/00251741311309643.

[11] EVROPSKÁ KOMISE. Velké záměry pro malé podniky-co dělá EU pro MSP. Lucemburk: Úřad pro publikace EU, 2011.

[12] FETISOVOVÁ, E., et al. Aktuálne problémy financií malých a stredných podnikov. Bratislava: Ekonóm, 2012. ISBN 978-80-225-3366-9.

[13] FETISOVOVÁ, E., VLACHYNSKÝ, K., SIROTKA, V. Financie malých a stredných podnikov. Bratislava: Ekonómia, 2004. ISBN 808904-78-74.

[14] GE MONEY BANK. Motivy, které vedou lidi k podnikání [online]. MAFRA, 2014 [cit. 2014-0307]. Available from: http://ekonomika.idnes.cz/ specialni-priloha.aspx?y=ekonomika\%2Fmotivyktere-vedou-lidi-k-podnikani.htm.

[15] GERŠL, A., JAKUBÍK, P. Modely bankovního financování českých podniků a úvěrové riziko [online]. Praha: Česká národní banka, 2011 [cit. 2013-07-11]. 10 p. (PDF). Available from: http://is.vsfs.cz/el/6410/zima2012/N_RRFS/ FS_2008-2009_clanek_3.pdf.

[16] GfK CZECH. Průzkum: Podnikatelé jsou vnímaní pozitivněji. [online]. Praha: GfK, 2013 [cit. 2013-07-11]. Available from: http://www. podnikatel.cz/clanky/pruzkum-podnikatelejsou-vnimani-pozitivneji/.

[17] HÁJEK, L., REŽNÝ, L. 20 let vývoje české ekonomiky - srovnání se Slovenskem. E+M Ekonomie a Management. 2014, Vol. 17, Iss. 1, pp. 19-31. ISSN 1212-3609. doi:10.15240/ tul/001/2014-1-002.

[18] HAMILTON, R. T. How firms grow and the influence of size and age. International Small Business Journal. 2012, Vol. 30, No. 6, pp. 611-621. ISSN 0266-2426. doi:10.1177/0266242610383446.

[19] HASLE, P., et al. The working environment in small firms: Responses from owner-managers. International Small Business Journal. 2012,
Vol. 30, No. 6, pp. 622-639. ISSN 0266-2426. doi:10.1177/0266242610391323.

[20]HENDERSON, J.,WEILER, S.Entrepreneurs and job growth: probing the boundaries of time and space. Economic Development Quarterly. 2010, Vol. 24, Iss. 1, pp. 23-32. ISSN 08912424. doi:10.1177/0891242409350917.

[21] KARPAK, B., TOPCU, I. Small medium manufacturing enterprises in Turkey: an analytic network process framework for prioritizing factors affecting success. International Journal of Production Economics. 2010, Vol. 125, Iss. 1, pp. 60-70. ISSN 0925-5273. doi:10.1016/ j.ijpe.2010.01.001.

[22] KEH, H. T., NGUYEN, T. T. M., NG, H. $P$. The effect of entrepreneurial orientation and marketing information on the performance of SMEs. Journal of Business Venturing. 2007, Vol. 22, Iss. 4, pp. 592-611. ISSN 0883-9026. doi:10.1016/j.jbusvent.2006.05.003.

[23] KIRSCHENBAUM, K., NORDEN, L. The Relationship between Borrower Risk and Loan Maturity in Small Business Lending. Journal of Business Finance \& Accounting. 2012, Vol. 39, Iss. 5-6, pp. 730-757. ISSN 1468-5957. doi:10.1111/j.1468-5957.2012.02285.x.

[24] KNÖRR, H., ALVAREZ, C., URBANO, D. Entrepreneurs or employees: a cross cultural cognitive analysis. International Entrepreneurship and Management Journal. 2013, Vol. 9, Iss. 2, pp. 273-294. ISSN 15547191. doi:10.1007/s11365-012-0235-2.

[25] KRAUS, S., RIGTERING, J. P. C., HUDGES, M., HOSMAN, V. Entrepreneurial orientation and the business performance of SMEs: a quantitative study from the Netherlands. Review of Managerial Science. 2012, Vol. 6, Iss. 2, pp. 161-182. ISSN 1863-6691. doi:10.1007/ s11846-011-0062-9.

[26] KRIŠTOFÍK, P. Poučenia z krízového vývoja. Finančný manažment [online]. 2010 [cit. 2010-01-06] Available from: http://www. financnymanazment.sk/2010-1/6-2010/ Poucenia-z-krizoveho-vyvoja.

[27] LASAGNI, A. How Can External Relationships Enhance Innovation in SMEs? New Evidence for Europe. Journal of Small Business Management. 2012, Vol. 50, Iss. 2, pp. 310-339. ISSN 1540-627X. doi:10.1111/j.1540627X.2012.00355.x.

[28] LAZAREVIČ, A. Česko je jedním z rájů korupce [online]. Praha: Mešec, 2014 [cit. 201403-07]. Available from: http://www.mesec.cz/ aktuality/cesko-je-jednim-z-raju-korupce/. 
[29] MÁJKOVÁ-SOBEKOVÁ, M. Analýza bariér a faktorov financovania malých a stredných podnikov v SR. Ekonomický časopis. 2011, Vol. 59, No. 10, pp. 1033-1046. ISSN 0013-3035.

[30] MENDES, I. A. F. Senior Managers and SMEs' Propensity to Quality Improvement. E+M Ekonomie a Management. 2013, Vol. 16, Iss. 4, pp. 89-103. ISSN 1212-3609.

[31] MINISTERSTVO PRŮMYSLU A OBCHODU ČESKÉ REPUBLIKY. Zpráva o vývoji malého a středního podnikání a jeho podpoře v roce 2012 [online]. Praha: MPO, 2013 [cit. 2014-03-07]. Available from: http://www.edukol.cz/publikace/ zprava_o_vyvoji_msp_v_roce_2012.pdf.

[32] MINISTERSTVO HOSPODÁRSTVA SLOVENSKEJ REPUBLIKY. Analýza stavu MSP [online]. Bratislava: MH SR, 2013 [cit. 2014-07-07]. Available from: www.economy.gov. sk/ext_dok-analyza-stavu-msp/142099c?ext.

[33] MOLNÁR, Z., STŘELKA, J. Competitive Intelligence for Small and Middle Enterprises. E+M Ekonomie a Management. 2012, Vol. 15, Iss. 3, pp. 156-170. ISSN 1212-3609.

[34] MORO, A., FINK, M. Loan managers' trust and credit access for SMEs. Journal of Banking \& Finance. 2013, Vol. 37, Iss. 3, pp. 927-936. ISSN 0378-4266. doi:10.1016/j. jbankfin.2012.10.023.

[35] NÁRODNÁ AGENTÚRA PRE ROZVOJ MALÉHO A STREDNÉHO PODNIKANIA. Správa o stave malého a stredného podnikania v Slovenskej republike v roku 2012. Bratislava: NADSME, 2013.

[36] NÁRODNÁ AGENTÚRA PRE ROZVOJ MALÉHO A STREDNÉHO PODNIKANIA. Názory verejnosti na podnikanie a podnikatelov $v$ Slovenskej republike [online]. Bratislava: NADSME, 2010 [cit. 2014-03-07]. Available from: http://www.sbagency.sk/sites/default/files/ prieskum_nazorov verejnosti_na podnikatelov_a podnikanie.pdf.

[37] NEUBERGER, D., RÄTHKE, S. Microenterproses and multiple relationships: The case of professionals. Small Business Economics. 2009, Vol. 32, pp. 207-229. ISSN 0921-898X. doi:10.1007/s11187-007-9076-8.

[38] PODNIKATEL.CZ. Většina podnikatelů tráví papírováním celé dny, byrokracie sa prý zvyšuje [online]. 2010 [cit. 2014-03-03]. Available from: //http://www.podnikatel.cz/clanky/vetsinapodnikatelu-travi-papirovanim-nekolik-dnibyrokracie-se-navic-zvysuje/.
[39] PwC. Pro české podnikatele může být snažši zvládnout hospodářskou krizi, než uřídit růst své firmy [online]. Praha: PwC, 2010 [cit. 2014-03-03]. Available from: http://www.pwc. com/cz/cs/zkouska-ohnem/zkouska-ohnemtiskova-zprava.jhtml.

[40] SLOVENSKÁ OBCHODNÁ A PRIEMYSELNÁ KOMORA. Firmy vnímajú podnikatelské prostredie na Slovensku negatívne [online]. Bratislava: SOPK, 2014 [cit. 2014-03-03]. Available from: http://banky.sk/43212-sk/ firmy-vnimaju-podnikatelske-prostredie-naslovensku-negativne.php.

[41] SOININEN, J., MARTIKAINEN, M., PUUMALAINEN, K., KYLÄHEIKO, K. Entrepreneurial orientation: Growth and profitability of Finnish small- and mediumsized enterprises. International Journal of Production Economics. 2012, Vol. 140, Iss. 2, pp. 614-621. ISSN 0925-5273. doi:10.1016/j. ijpe.2011.05.029.

[42] ZAPLETALOVÁ, Š. The Approach to the Internationalization of Entrepreneurial Activities of Czech Companies. E+M Ekonomie a Management. 2012, Vol. 15, Iss. 4, pp. 84-96. ISSN 1212-3609.

prof. Ing. Jaroslav Belás, PhD.

Tomas Bata University in Zlín

Faculty of Management and Economics Department of Enterprise Economics belas111@gmail.com

Ing. Valér Demjan, PhD.

The Banking Institute of Prague Department of Banking valer@valer.sk

assoc. prof. Ing. Jozef Habánik, PhD. Alexander Dubček University of Trenčín Faculty of Social-Economics Relationship jozef.habanik@ tnuni.sk

Ing. Mária Hudáková, PhD. University of Žilina

Faculty of Special Engineering Maria.Hudakova@fsi.uniza.sk

assoc. prof. Ing. Juraj Sipko, PhD., MBA

Paneuropean University Faculty of Economics and Business jurajsipko@gmail.com 


\title{
Abstract
}

\section{THE BUSINESS ENVIRONMENT OF SMALL AND MEDIUM-SIZED ENTERPRISES IN SELECTED REGIONS OF THE CZECH REPUBLIC AND SLOVAKIA}

\author{
Jaroslav Belás, Valér Demjan, Jozef Habánik, Mária Hudáková, Juraj Sipko
}

The aim of this article was to define and compare current trends in the business environment of small and medium-sized enterprises in selected regions of the Czech Republic and Slovakia. In accordance with the objective, motivational factors, status in the society, levels of corruption, current business risks, approaches to loan financing, the ability to manage financial risks and business optimism in the business environment have been examined. In 2013, research into entrepreneurs' opinions in the Czech Republic (Zlin Region) and Slovakia (Zilina and Trencin Regions) was conducted. These neighbouring regions have similar economic parameters. According to our findings, the most important motive for starting a business in the Czech Republic was to have a job. In Slovakia, the most important motive for starting a business was money. The results of our research confirmed that the societies in both countries perceived the position of entrepreneurs relatively negatively. In both countries, entrepreneurs negatively noted the approach of the state to their needs and relatively high levels of corruption. Nowadays, the most important business risk was the market risk followed by financial and personal risks. Due to a deterioration of the business environment, the performance of small and medium-sized enterprises has declined by at least $15 \%$ in both countries. In the Czech Republic, approximately $43 \%$ of entrepreneurs stated that banks accept their needs and behave appropriately to them. The positive perception of banks was significantly lower in Slovakia: 23\% of entrepreneurs in the Zilina Region and 35\% in the Trencin Region. Many Czech and Slovak entrepreneurs indicated that they are able to manage financial risks in their companies. Despite the significant deterioration in the business environment, SMEs demonstrate business optimism, with about $90 \%$ of the entrepreneurs in both countries believing that their company will survive the next five years.

Key Words: Small and medium-sized enterprises, business environment, motives for business, business risks, SMEs in society, business optimism.

JEL Classification: L26, O16, G32, G21.

DOI: 10.15240/tul/001/2015-1-008 